\title{
Effect of Viral Infection on Carbohydrate and Chlorophyll Contents in Ginger (Zingiber officinale Rosc.)
}

\author{
N. Ananthu* and K. Umamaheswaran
}

College of Agriculture, Vellayani, Thiruvananthapuram, Kerala, India

*Corresponding author

\begin{abstract}
A B S T R A C T
Keywords

Ginger, Mosaic disease,

Carbohydrate,

chlorophyll,

Degeneration,

Metabolic

alterations

Article Info

Accepted:

10 May 2019

Available Online:

10 June 2019

\section{Introduction}

Ginger is one of the earliest recognized oriental spices. From time immemorial, it is being cultivated in India for both as fresh vegetable and dried spice. The ginger family is a tropical group, especially abundant in the Indo- Malaysian region. This family consists of more than 1200 plant species in 53 genera. It is one of the oldest spice crops of the world like cinnamon, clove and pepper. It is being cultivated in several parts of the world, mainly in the countries like India, China,

Japan, Taiwan, Nigeria, Australia etc. Kerala has a good contribution in the total production of ginger. A high proportion of the dry ginger from the state, both bleached and unbleached is exported to overseas countries. India exports ginger mostly to the countries viz. USA, UK, Saudi Arabia, Canada and Singapore. Ginger is used principally as an ingredient in various spice blends, food processing and beverage industries for flavouring coffee and tea. A number of diseases are known to cause damage to ginger in India. The important of them are leaf spot,
\end{abstract}


soft rot and bacterial wilt. Among the spice crops the viral diseases are of very little knowledge. The viral diseases are nowadays increasing in spice crops because of their increase in area of cultivation. In recent years, ginger has been observed to suffer from a mosaic disease throughout the cultivating tracts and also in the fields of Instructional Farm, College of Agriculture, Vellayani. In view of the importance of viral diseases, this study was undertaken to study the impact of this disease on carbohydrate and chlorophyll content of the crop.

\section{Materials and Methods}

\section{Estimation of total carbohydrates}

The determination of total carbohydrates was done through Anthrone method (Hedge and Hoftreiter, 1962). In this procedure, $100 \mathrm{mg}$ of the sample was taken in a boiling tube and it was subjected to hydrolysis by keeping in a boiling water bath for three hours with $5 \mathrm{ml}$ of $2.5 \mathrm{~N} \mathrm{HCl}$. After this it was cooled down to room temperature. Solid sodium carbonate was added into the tube for neutralization until the effervescence ceased and it was made upto $100 \mathrm{ml}$. The samples were centrifuged at $5000 \mathrm{rpm}$ for 15 minutes at $4^{\circ} \mathrm{C}$. From this the supernatant was collected and $0.5 \mathrm{ml}$ was taken as aliquot for analysis. The aliquot was made up to $1 \mathrm{ml}$ using distilled water and $4 \mathrm{ml}$ of anthrone reagent was added into it. The mixture was heated for 8 minutes in a boiling water bath. After heating it was cooled down rapidly and the green- dark green colour was read at $630 \mathrm{~nm}$ in a spectrophotometer (Eppendorf Bio Spectrophotometer).

\section{Estimation of chlorophyll content}

For chlorophyll estimation, $1 \mathrm{~g}$ of freshly cut and well mixed representative samples of leaves was taken. It was ground to a fine pulp with addition of $20 \mathrm{ml}$ of $80 \%$ chilled acetone. It was centrifuged at $5000 \mathrm{rpm}$ for five minutes at $4^{\circ} \mathrm{C}$ and the supernatant was transferred into a $100 \mathrm{ml}$ volumetric flask. The residue was again ground in $20 \mathrm{ml}$ of $80 \%$ chilled acetone, centrifuged as earlier and the supernatant was transferred to the same volumetric flask. This procedure was repeated until the residue became colourless. The mortar and pestle were washed thoroughly with $80 \%$ acetone and the clear washings were collected in the volumetric flask. The volume was made upto $100 \mathrm{ml}$ using $80 \%$ acetone. The absorbance values were read at 645 and $663 \mathrm{~nm}$ in a spectrophotometer against the blank, $80 \%$ acetone. Chlorophyll a, chlorophyll b and total chlorophyll contents were calculated using the following formulae:

mg chlorophyll per gram tissue:

Chlorophyll a: [12.7 (A 663) - 2.69 (A 645)] $X \frac{\mathrm{v}}{1000 w}$

Chlorophyll b: [22.9 (A 645) - 4.68 (A 663)] $\mathrm{X} \frac{\mathrm{v}}{1000 \mathrm{w}}$

Total chlorophyll: [20.2(A 645) + 8.02 (A 663)] $X \frac{\mathrm{v}}{1000 w}$

Where, $\mathrm{A}=$ absorbance at specific wavelength,

$\mathrm{v}=$ final volume of the chlorophyll extract and

$\mathrm{w}=$ fresh weight of the tissue extracted.

\section{Results and Discussion}

\section{Estimation of total carbohydrates}

The total carbohydrate content in healthy and inoculated plants was estimated and is presented in Table 1. The results indicated that healthy plants showed more carbohydrate content with respect to the infected plants. In 
both healthy as well as infected plants, the carbohydrate level was observed to be increasing upto 60 and 90 DAI, after which a decline was observed. The healthy plants exhibited the highest carbohydrate level at 60 DAI and it was observed to be $23.61 \mathrm{mg} \mathrm{g}^{-1}$. The infected plants showed the highest carbohydrate level at 90 DAI and it was 14.72 $\mathrm{mg} \mathrm{g}^{-1}$, and thereafter declined to $11.92 \mathrm{mg}$ $\mathrm{g}^{-1}$ and $7.26 \mathrm{mg} \mathrm{g}^{-1}$ respectively.

\section{Estimation of chlorophyll}

The estimation of chlorophyll in healthy and infected plants comprised of estimations of chlorophyll a, chlorophyll b and total chlorophyll content at different days of interval. Throughout the estimation the chlorophyll content was found much lower in infected plants when compared to healthy plants. The healthy plants showed an increase in total chlorophyll content, from $1.73 \mathrm{mg} \mathrm{g}^{-1}$ at $30 \mathrm{DAI}$ to $1.97 \mathrm{mg} \mathrm{g}^{-1}$ at $120 \mathrm{DAI}$, whereas infected plants showed a decline from 1.14 $\mathrm{mg} \mathrm{g}^{-1}$ to $0.56 \mathrm{mg} \mathrm{g}^{-1}$ during the same period of observation. The chlorophyll a content of infected plants declined to the level of 0.37 $\mathrm{mg} \mathrm{g}^{-1}$ at 120 DAT from $0.74 \mathrm{mg} \mathrm{g}^{-1}$ at 30 DAI. During the same period the healthy plants had an increase in chlorophyll a content from $1.25 \mathrm{mg} \mathrm{g}^{-1}$ to $1.44 \mathrm{mg} \mathrm{g}^{-1}$. Similarly in healthy plants, the chlorophyll $b$ content increased from $0.49 \mathrm{mg} \mathrm{g}^{-1}$ at 30 DAI to 0.53 $\mathrm{mg}^{-1}$ at 120 DAI. But the chlorophyll $\mathrm{b}$ content of infected plants showed a reduction of $0.19 \mathrm{mg} \mathrm{g}^{-1}$ at $120 \mathrm{DAI}$ from $0.40 \mathrm{mg} \mathrm{g}^{-1}$ at 30 DAI. The chlorophyll a, chlorophyll $\mathrm{b}$ and total chlorophyll contents showed its peak at 60 DAI, after which response was erratic (Table 2).

The results revealed that the infected plants showed a significant reduction in the chlorophyll content than in healthy plants due to the viral infection. Viral diseases have a huge impact on production, productivity and quality of a crop. The viruses depend on a host plant for its replication. They alter the metabolic system of the host and bring drastic effects over the hosts. Carbohydrate and chlorophyll alterations due to viral infections are very widely reported and discussed by various scientists.

The total carbohydrate content was found significantly higher in healthy plants than that of infected plants at all stages of infection. The results are in line with the findings of Ramiah (1978) who reported that there was decrease in synthesis of total carbohydrates in infected leaves of susceptible cowpea. A decrease of total sugar and starch in leaf tissues of sunhemp infected with Bean mosaic virus was reported by Singh and Singh (1980). The observation of Singh and Singh (1984) was the virus infection decreased the total sugar and starch in cowpea cultivars infected with Southern bean mosaic virus and Cowpea mosaic virus. Johri and Pandhi (1985) also reported similarly that the carbohydrate level declined positively with severity of disease symptoms in case of yellow vein mosaic of okra. Similarly BYVMV infected okra plants were reported with low reducing sugars and increase in total sugar and non-reducing sugar contents by Sarma et al., (1995). Thind et al., (1996) reported that the amount of total sugars and starch decreased in black gram infected with Yellow mosaic virus when compared with healthy plants. Sutha et al., (1998) reported that TSWV infection reduced the concentration of total, reducing and nonreducing sugars of tomato fruits. Mali et al., (2000) reported that Mungbean yellow mosaic virus (MYMV) infection on moth bean resulted in significant reduction of total soluble carbohydrates in susceptible cultivar when compared to resistant cultivar. Sindhu (2001) also reported a reduction in the level of carbohydrate content in susceptible varieties inoculated with BlCMV compared to 
healthy control. Post infection decrease in reducing sugars, non-reducing sugars and total sugars in the plants infected with TLCV was reported (Raghavendra, 2002). A significant reduction in total sugar content in BlCMV infected cowpea plants was observed by (Krishnapriya, 2015). Findings of the present study are in agreement with previous reports of decreased starch content in virus infected plants. This might be due to the alterations in photosynthesis and as a result of disruption of normal phloem transport (Alagianagalingam and Ramakrishnan, 1979; Estellita et al., 1993). All these findings are in accordance with the present investigation.

Table.1 Changes in total carbohydrate content of ginger leaves due to viral infection, $\mathrm{mg} \mathrm{g}^{-1}$

\begin{tabular}{|c|c|c|c|}
\hline \multirow{2}{*}{$\begin{array}{c}\text { Days after } \\
\text { infection }\end{array}$} & \multicolumn{2}{|c|}{$\begin{array}{c}\text { Change in carbohydrate content (mg } \\
\text { g-1 on fresh weight basis)* }\end{array}$} & $\begin{array}{c}\text { Per cent increase or } \\
\text { decrease over healthy }\end{array}$ \\
\hline 30 & Healthy & Infected & \\
\hline 60 & 14.42 & 8.62 & 40.22 \\
\hline 90 & 23.61 & 11.39 & 51.76 \\
\hline 120 & 16.08 & 14.72 & 8.46 \\
\hline
\end{tabular}

CD at 5\%: $\quad$ Healthy $X$ Infected: 1.50 ; DAI: 1.06

* Mean of three replications

Table.2 Changes in total chlorophyll content of ginger leaves in response to virus infection, $\mathrm{mg} \mathrm{g}^{-1}$

\begin{tabular}{|c|c|c|c|c|c|c|}
\hline \multirow{3}{*}{$\begin{array}{l}\text { Days } \\
\text { after } \\
\text { infection }\end{array}$} & \multicolumn{6}{|c|}{ Changes in chlorophyll content (mg g-1 on fresh weight basis)* } \\
\hline & \multicolumn{2}{|c|}{$\mathrm{a}$} & \multicolumn{2}{|c|}{ B } & \multicolumn{2}{|c|}{ Total } \\
\hline & Healthy & Infected & Healthy & Infected & Healthy & Infected \\
\hline 30 & 1.25 & 0.74 & 0.49 & 0.40 & 1.73 & 1.14 \\
\hline 60 & 1.76 & 0.90 & 0.82 & 0.44 & 2.58 & 1.34 \\
\hline 90 & 1.28 & 0.40 & 0.51 & 0.21 & 1.79 & 0.61 \\
\hline 120 & 1.44 & 0.37 & 0.53 & 0.19 & 1.97 & 0.56 \\
\hline \multicolumn{7}{|c|}{$\begin{array}{l}* \text { Mean of three replications } \\
\mathrm{CD} \text { at } 5 \%\end{array}$} \\
\hline $\begin{array}{l}\text { Healthy Vs. } \\
\text { DAI }\end{array}$ & $\begin{array}{ll}\text { ed } & 0.077 \\
0.109\end{array}$ & $\begin{array}{l}0.023 \\
0.032\end{array}$ & .091 & & & \\
\hline
\end{tabular}

The estimation of chlorophyll in healthy and infected plants comprised of estimations of chlorophyll a, chlorophyll b and total chlorophyll content at different days of interval. Throughout the estimation the chlorophyll content was found much lower in infected plants than healthy plants. Chlorophyll degradation is a common characteristic phenomenon in viral infections and the present findings are in terms with that of other reports. Alagianagalingam and Ramakrishnan (1979) observed a reduction in chlorophyll content in cassava leaves infected by the virus as compared to healthy leaves. Ayanru and Sarma (1982) also reported the similar reduction of chlorophyll $a$ and $b$ in mosaic virus infected cassava plants. The reduction in chlorophyll content of okra leaves due to BYVMV infection was reported (Sarma et al., 1995). Similarly a decline in 
chlorophyll content of mung bean plants infected with yellow mosaic virus was observed by Thind et al., (1996). Vasanthi and Shanmugam (2003) observed lowest content of chlorophyll a, b and total chlorophyll in ICMV infected cassava as compared to healthy ones. Total chlorophyll, chlorophyll a and chlorophyll $b$ were found to be lower in mung bean plants infected by Mungbean yellow mosaic virus (MYMV) (Momol and Pernezny, 2006). Arpita and Subrata (2008) observed a gradual fall in green pigments like chlorophyll a, b and total chlorophyll contents in mesta at different stages of yellow mosaic virus infection and there was alteration of the ratio between chlorophyll $a$ and $b$ which affects the photosynthetic efficiency. Philip (2010) reported a reduction in chlorophyll $\mathrm{a}$ and $\mathrm{b}$ in Cassava mosaic geminiviruses (CMG) infected cassava leaves compared to healthy leaves. Chlorophyll pigments a and $\mathrm{b}$ as well as total chlorophyll were found lower in finger millet plants due to mottle streak virus infection. From the studies of Ramiah (1978) and Ahmed et al., (1986) the possible reason for reduction of chlorophyll content in virus infected plants is the increased activity of chlorophyllase enzyme in them.

\section{References}

Ahmed, N., Thakur, M. R. and Bajaj, K. L. 1986. Nature of resistance and effect of Yellow vein mosaic virus on moisture, chlorophyll, chlorophyllase and carbohydrate contents of okra. Veg. Sci. 13: 339-353.

Alagianagalingam, M. N. and Ramakrishnan, K. 1979. Effect of cassava mosaic on photosynthetic pigments and photosynthesis. Auara. 7: 120-123.

Arpita, C. and Subrata, K. G. 2008. Alterations in biochemical components in mesta plants infected with yellow vein mosaic disease. Braz. J. Pl. Physiol. 20: 267-275.

Ayanru, D. K. G. and Sharma, V. C. 1982. Effects of cassava mosaic disease on certain leaf parameters of field grown cassava and clones. Phytopath. 72: 1057-1059.

Bhagat, A. P. and Yadav, B. P. 1997. Biochemical changes in BYVMV infected leaves of bhendi. J. Mycol. Pl. Pathol. 27: 94-95.

Estellita, S., Suma, A., Luckins, C. B. and Mallika, V. K. 1993. Flower bud anatomy of kokkan affected banana. J. Tropic Agric., 31: 277-278.

Hedge, J. E. and Hoftreiter, B. T. 1962. Methods. In: Whistler, R. L. and Be Miller, J. N. (eds.), Carbohydrate Chemistry. Academic Press, New York, p. 420.

Johri, J. K. and Pandhi, B. 1985. Effect of yellow vein mosaic on physiology of okra. Indian J. Virol. 1: 61-68.

Krishnapriya, P. J. 2015. Immunomolecular detection and characterization of potyviruses infecting cowpea (Vigna unguiculata (L.) Walp.) and papaya (Carica papaya L.). M. Sc (Ag). Thesis, Kerala Agricultural University, Thrissur., $198 \mathrm{p}$.

Mali, P. C., Burman, U. and Lodha, S. 2000. Effect of planting dates and development of yellow mosaic virus on biochemical constituents of moth bean genotypes. Indian Phytopath. 53: 377383.

Momol, T. M. and Pernezny, K. L. 2006. Specific common diseases. Florida Plant Disease Management Guide Everglades Research and Education Centre. University of Florida. Florida Cooperative Extension Service, IFAS. PDMG. 3: 53.

Philip, T. 2010. Cassava mosaic virus induced physio- biochemical changes in the 
leaves of tapioca (Manihotutilisima Pohl.). Int. J. Plant Protec., 3: 31-33.

Raghavendra, A. S. 2002. Histology, Biochemical studies and management of tomato leaf curl. M. Sc (Ag) thesis, University of Agricultural Sciences, Dharwad, $63 \mathrm{p}$.

Ramiah, M. 1978. Studies on mosaic disease of cowpea in relation to disease resistance. Ph. D. thesis, Tamil Nadu Agricultural University, Coimbatore, $105 \mathrm{p}$.

Sarma, U. C., Bhagabati, K. N. and Sarkar, C. R. 1995. Effect of yellow vein mosaic virus infection on some chemical constituents of bhendi (Abelmoschus esculentus (L.) Moench). Indian J. Virol. 11: 81-83.

Sindhu, A. R. 2001. Biochemical basis of resistance against Blackeye cowpea mosaic virus in cowpea (Vigna unguiculata (L.) Walp.). M. Sc (Ag) thesis, Kerala Agricultural University, Thrissur., $65 \mathrm{p}$.
Singh, R. and Singh, A. K. 1980. Metabolic changes in leaf tissue of sunhemp infected with Common bean mosaic virus. Egyptian J. Bot. 21: 113-119.

Singh, R. and Singh, A. K. 1984. Effect of Southern bean mosaic virus infection on the leaf protein concentration in cowpea cultivars. Curr. Sci. 53: 390.

Sutha, R., Ramiah, M. and Rajappan, K. 1998. Effect of Tomato spotted wilt virus infection on the quality of tomato fruits. Int. J. Tropic. Pl. Dis., 16: 261265.

Thind, S. K., Monga, P. K., Kaur, N. and Cheema, S. S. 1996. Analysis of some biochemical and micronutrient constituents of Yellow mosaic virus infected mung. Indian J. Virol. 12: 157159.

Vasanthi, V. J. and Shanmugam, V. 2003. Physiological changes in cassava (Manihot esculenta Crantz) infected with Indian mosaic geminivirus. Pl. Dis. Res. 18: 196-198.

\section{How to cite this article:}

Ananthu, N. and Umamaheswaran, K. 2019. Effect of Viral Infection on Carbohydrate and Chlorophyll Contents in Ginger (Zingiber officinale Rosc.). Int.J.Curr.Microbiol.App.Sci. 8(06): 862-867. doi: https://doi.org/10.20546/ijcmas.2019.806.104 